\section{ANALISIS FAKTOR-FAKTOR YANG MEMPENGARUHI PRODUKTIVITAS TENAGA KERJA WANITA DAN KOTRIBUSI PENDAPATAN (Studi Kasus Pada Usaha Belah Pinang Di Desa Paya Rangkuluh
Kecamatan Kuta Blang Kabupaten Bireuen)}

\author{
Meli Orlian ${ }^{* a}$, Ratna ${ }^{* b}$ \\ *Fakultas Ekonomi dan Bisnis Universitas Malikussaleh \\ a Corresponding author: meli.orlian64@gmail.com \\ b ratnahus@yahoo.com
}

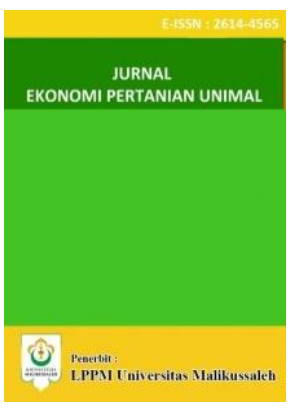

A R T I C L E I N F O R M A T I O N

Keywords:

wages, age, education level, total household income and productivity of female labor and income contribution.

\section{A B S T R A C T}

The purpose of this study is to look at the factors that influence the productivity of female labor and income contribution (case study in Pinang split business in Payarangkuluh village, KutaBlang District, Bireuen Regency). The data used in this study are primary data obtained from 80 respondents. Data analysis method used is multiple linear regression. The results showed that the wages and total household income have a positive effect on the productivity of female labor, then age and level of education have a negative effect on the productivity of female labor, while together the variables of wages, age, level of education and total household income affected positively on the productivity of female labor in the village of Payarangkuluh Kuta Blang District Bireuen Regency.

\section{PENDAHULUAN}

Produktivitas tenaga kerja wanita merupakan hasil produksi wanita dalam menjalankan suatu kegiatan yang akan memperoleh penghasilan dalam memenuhi kebutuhan rumah tangganya. Produktivitas tenaga kerja wanita akan memunculkan sikap mental yang selalu berpandangan bahwa wanita tidak hanya memjadi beban dalam negara namun dapat menghasilkan suatu pendapatan bagi keluarga bahkan negara, salah satunya adalah usaha belah pinang Kabupaten Bireuen khususnya untuk desa Paya Rangkuluh Kecamatan Kuta Blang merupakan salah satu desa yang banyak mempekerjakan dan menghasilkan karya dari hasil produktivitas wanita.

Gaji atau upah adalah balas jasa yang diterima seseorang atas pekerjaan yang dilakukan baik itu berupa barang ataupun jasa yang diberikan dalam jangka waktu dapat perhari, perminggu dan perbulan (Jaya, 2011), gaji dan upah sangat menentukan dalam produktivitas karena dengan adanya gaji dan upah yang maksimal akan membuat semangat para pekerja sehingga produktivitas akan semakin ditingkatkan.

Penduduk pada usia 15-55 tahun yang lebih utama laki-laki memiliki kewajiban mencari rezeki. Namun masyarakat yang berusia diatas 55 tahun sudah akan menurun untuk produktivitas kerjanya (Simanjuntak, 2001), para pekerja memiliki usia rata-rata 30 keatas di usaha ini.

Pendidikan merupakan kegiatan yang mendasar harus ada dalamk kegiatan manusia untuk memperoleh ilmu yang bermanfaat pendidikan sangat diperlukan dalam bekerja atau skill yang dimiliki karena akan meningkatkan produktibvitas usaha yang akan mengembangkan diri (Undang-Undang No. 20 Tahun 2003, n.d.)

Pendapatan merupakn jumlah uang yang diperoleh seseorang setelah memberikan kebutuhan yang diinginkan dari pemilik pekerjaan (Jaya, 2011), wanita ingin bekerja karena ingin memenuhi kebutuhan keluarganya yang dianggap masih berkurang, sehingga para wanita memiliki inisiatif untuk bekerja sehingga mambantu membangkitkan kontribusi keluarganya. 
Penelitian ini didukung penelitian yang dilakukan oleh (Purwanti, 2014b) dengan variabeel yang diteliti yaitu jumlah tanggungan keluarga, pendapatan dan produtivitas tenaga kerja wanita pada industri kerupuk.

Penelitian dari (Bonanta, 2015) dengan variabel penelitian upah, jumlah tanggungan keluarga, pendapatan suami dan produktivitas wanita pada industri Makanan di Provinsi Riau bahwa variabel yang diteliti terhadap produkstivitas wanita pada industri Makanan.

Penelitian dari (Farida, 2011) dengan variabel yang diteliti yaitu tingkat pendidikan, total pendapatan dan produktivitas perempuan bekerja sektor informal pada ekonomi keluarga di Kota Pekanbaru bahwa semua variabel yang diteliti juga berpengaruh terhadap produktivitas pendapatan perempuan bekerja sektor informal.

Tujuannya untuk mengetahui pengaruh upah, usia, tingkat pendidikan, total pendapatan RT berpengaruh terhadap produktivitas tenaga kerja wanita pada usaha belah pinang di Desa Paya Rangkuluh Kecamatan Kuta Blang Kabupaten Bireuen.

\section{KAJIAN TEORITIS}

\section{Produktivitas Tenaga Kerja Wanita}

Produktivitas adalah sebuah konsep yang menggambarkan hubungan antara modal,tanah, energy sebagai sumber menghasilkan hasil tersebut (Swastha, 2000).

Menurut (Fair, 2007) produktivitas merupakan hasil dari input yang dilakukan untuk menghasilkan output.

Berdasarkan dari pakar diatas dapat diambil kesimpulan produktivitas merupakan kemampuan menghasilkan lebih banyak produksi didalam perusahaan.

Menurut penelitian dari (Purwanti, 2014a) dengan judul pengaruh total angota yang harus dibiayai, pendapatan, pendidikan, usia terhadap produtivitas TKW pada industri kerupuk kedelai memakai metode regresi linier berganda bahwa semua faktor yang diteliti berpengaruh terhadap produktivitas TKW.

\section{Upah Tenaga Kerja Wanita}

Upah adalah balas jasa yang diperoleh pekerja atas pekerjaan yang dilakukannya (Rahman, 2012).

Sedang menurut (Gilarso, 2013) diartikan sebagai balas jasa atas karya yang disepakati awal melakukan pekerjan.
Berdasarkan para pakar diatas maka upah tenaga kerja wanita merupakan pembayaran balas jasa pemberi kerjaa kepada pekerja wanita atas balas jasa yang diberikan atas pekerjaan.

Penelitian dari (Purwanti, 2014a) dengan judul pengaruh jtoatal yang harus dibiayai dalam keluarga, pendapatan, pendidikan, usia dan upah terhadap produtivitas TKW pada industri kerupuk kedelai memakai metode regresi linier berganda bahwa semua faktor yang diteliti berhubungan dengan produktivitas TKW.

\section{Usia}

Penduduk yang berusia 15-55 tahun yang terutama bagi pihak laki-laki yang mencari rezeki, namun untuk penduduk yang berusia siatas 55 tahun sudah akan menurun produktiviats dalam bekerja (Ardi, 2011).

Usia adalah lamanya waktu hidup seseorang dalam menjalani kehidupan secara normal (D, 2002). Usia merupakan ukuran adanya aktifitas manusia setiap harinya (Fair, 2007).

Berdasarkan para pakar diatas bahwa usia merupakan lamanya masa kehidupan seseorang untuk menjalani rutinas sehari-hari.

Penelitian dari (Suarbawa, I Wayan, Terimajaya I Wayan, 2016) tentang pengaruh, upah umur, jumlah tanggungan dan jam kerja terhadap produktivitas tenaga kerja wanita dengan metode penelitian regresi linier berganda bahwa semua variabel yang diteliti berpengaruh terhadap produktivitas tenaga kerja wanita.

\section{Tingkat Pendidikan}

Menurut (Djumransyah, 2004) mendefinisikan pendidikan sebagai proses perkembangan kecakapan seseorang dalam bentuk sikap dan perilaku yang berlaku dalam masyarakatnya.

Pendidikan juga bisa diartian sebagai tuntunan di dalam hidup tumbuhnya anak-anak (Undang-Undang No. 20 Tahun 2003, n.d.)

Berdasarkan pengertian dari pakar diatas maka dapat diambil kesimpulan bahwa tingkat pendidikan adalah proses pembelajaran untuk mengembangkan potensi diri dalam usaha mendewasakan dan mencerdaskan peserta didik.

Penelitian dari (Suarbawa, I Wayan, Terimajaya I Wayan, 2016) tentang pengaruh , upah umur, jumlah tanggungan dan jam kerja terhadap produktivitas TKW dengan metode penelitian regresi linier berganda bahwa semua variabel yang diteliti berpengaruh terhadap produktivitas TKW. 


\section{Pendapatan Rumah Tangga}

Pendapatan adalah totak anggaran yang diperoleh oleh rumah tangga pada waktu tertentu (biasanya satu tahun) (Samuelson, 2001).

Pendapatan keluarga merupakan total uang diterima setelah melakukan aktivitas baik dalam jangka waktu perhari, perminggu dan perbulan (Jaya, 2011).

Kesimpulan pendapatan dari beberapa pakar adalah pendapatan merupakan hasil yang diperoleh atau diterima dari pihak dimana yang bertanggung jawab atas pekerjaan seseorang untuk memenuhi kebutuhan keluarganya.

Penelitian dari (Suarbawa, I Wayan, Terimajaya I Wayan, 2016) dengan judul penelitian pengaruh , upah umur, jumlah tanggungan dan jam kerja terhadap produktivitas tenaga kerja wanita dengan metode penelitian regresi linier berganda bahwa semua variabel yang diteliti berpengaruh terhadap produktivitas tenaga kerja wanita.

\section{Kontribusi Pendapatan}

Kontribusi merupakan suatu yang diperoleh seseorang atas apa yang telah dikerjakan yang memberikan suatu manfaat untuk dirinya dan orang lain.

\section{Kerangka Konseptual}

\begin{tabular}{|c|}
\hline Upah TKW $\left(X_{1}\right)$ \\
\hline Usia TKW $\left(X_{2}\right)$ \\
\hline $\begin{array}{c}\text { Tingkat Pendidikan } \\
\text { TKW }\left(X_{5}\right)\end{array}$ \\
\hline $\begin{array}{c}\text { Total Pendapatan RT } \\
\left(X_{4}\right)\end{array}$ \\
\hline
\end{tabular}

Gambar 1 Kerangka Konseptual

\section{Hipotesis}

Berdasarkan kerangka konseptual maka dapat diambil kesimpulan sebagi berikut:

$H_{1}$ : Diduga upah tenaga kerja berpengaruh positif terhadap produktivitas tenaga kerja wanita pada usaha belah Pinang di Desa Paya Rangkuluh Kecamatan Kuta Blang Kabupaten Bireuen

$H_{2}$ : Diduga usia berpengaruh negatif terhadap produktivitas tenaga kerja wanita pada usaha belah Pinang di Desa Paya Rangkuluh Kecamatan Kuta Blang Kabupaten Bireuen

$H_{3}$ : Diduga tingkat pendidikan berpengaruh positif terhadap produktivitas tenaga kerja wanita pada usaha belah Pinang di Desa Paya Rangkuluh Kecamatan Kuta Blang Kabupaten Bireuen

$H_{4}$ : Diduga total pendapatan rumah tangga positif berpengaruh terhadap produktivitas tenaga kerja wanita pada usaha belah Pinang di Desa Paya Rangkuluh Kecamatan Kuta Blang Kabupaten Bireuen

\section{METODE PENELITIAN}

\section{Populasi}

Dari hasil survey yang peneliti lakukan sebanyak 12 usaha belah pinang di Desa Payarangkuluh Kecamatan Kutablang Kabupaten Bireuen, maka populasi penelitian ini yaitu wanita yang bekerja sebagai belah pinang yang berjumlah 80 responden wanita (Rekapan buku harian pada usaha Belang Pinang, 2019).

\section{Sampel}

Dalam menentukan jumlah sampel dihitung berdasarkan metode sensus, sampel pada penelitian ini sebanyak 80 responden wanita.

\section{Definisi Operasional Variabel}

1. Upah tenaga kerja wanita $\left(X_{1}\right)$ : pembayaran balas jasa pihak pekerja atas balas jasa yang diberikan kepada tempat bekerja. Diukur dengan satuan rupiah.

2. Usia tenaga kerja wanita $\left(X_{2}\right)$ : lamanya masa kehidupan seseorang untuk menjalani rutinas sehari-hari. Diukur dengan satuan tahun.

3. Tingkat Pendidikan tenaga kerja wanita $\left(X_{3}\right)$ : proses pembelajaran untuk mengembangkan potensi diri. Diukur dengan satuan tahun.

4. Total Pendapatan rumah tangga $\left(X_{4}\right)$ : hasil yang diperoleh atau diterima dalam bentuk uang selama kurun waktu tertentu. Diukur dengan satuan rupiah.

5. Produktivitas tenaga kerja wanita $(Y)$ : kemampuan menghasilkan lebih banyak produksi didalam perusahaan. Diukur dengan satuan $\mathrm{kg} / \mathrm{bulan}$.

\section{Metode Analisis data}

Untuk memecahkan masalah pada penelitian ini maka penulis melakukan analisis data dengan 
memakai metode kuantitatif dengan menggunakan alat statistik yaitu program Eviews versi 10 yang berupa metode Regresi Linier Berganda (RLB) sebagai berikut:

$$
\begin{gathered}
\operatorname{Ln} Y=\beta_{0}+\beta_{1} \operatorname{Ln} X_{1}+\beta_{2} X_{2}+\beta_{3} X_{3} \\
+\beta_{4} \operatorname{Ln} X_{4}+e i
\end{gathered}
$$

Keterangan:

$\begin{array}{ll}\operatorname{Ln} \boldsymbol{} & =\text { Produktivitas tenaga kerja wanita } \\ \boldsymbol{\beta}_{\mathbf{0}} & =\text { Konstanta } \\ \boldsymbol{\beta}_{\mathbf{1}} \boldsymbol{\beta}_{\mathbf{2}} \boldsymbol{\beta}_{\mathbf{3}} \boldsymbol{\beta}_{\mathbf{4}} & =\text { Koefisien Regresi } \\ \boldsymbol{L n} \boldsymbol{X}_{\mathbf{1}} & =\text { Upah tenaga kerja wanita } \\ \boldsymbol{X}_{\mathbf{2}} & =\text { Usia tenaga kerja wanita } \\ \boldsymbol{X}_{3} & =\text { Tingkat Pendidikan TKW } \\ \boldsymbol{L n} \boldsymbol{X}_{\mathbf{4}} & =\text { Total pendapatan rumah tangga } \\ \boldsymbol{e i} & =\text { Error Term }\end{array}$

\section{Uji Normalitas}

Uji normalitas dilihat untuk data terdistribusi secara normal atau tidak. Pengujian normalitas dapat dilakukan dengan menggunakan metode Jarque-Bera (J-B) (Widarjono, 2013).

Jika nilai probability dari statistik J-B lebih besar dari taraf kepercayaan $5 \%(0,05)$ berarti bahwa residul data berdistribusi normal. Sebaliknya jika nilai probability dari statistik J-B lebih kecil dari taraf kepercayaan 5\% $(0,05)$ berarti bahwa residul data tidak berdistribusi normal (Widarjono, 2013).

\section{Uji Asumsi Klasik}

Adapun uji asumsi klasik yang digunakan dalam penelitian ini adalah sebagai berikut.

\section{Uji Heteroskedastisitas}

Uji heteroskedastisitas dilakukan untuk melihat apakah data dalam penelitian terjadi persamaan (Ghozali, 2010).

Metode pengujian yang lain dapat digunakan adalah metode White. Dasar Pengambilan keputusan, jika nilai probabilitas dari Obs $* R$-Squared $>X^{2}$ tabel, maka ada indikasi terjadi heteroskedastisitas; jika nilai probabilitas dari $O b s^{*} R$-Squared $<X^{2}$ tabel, maka model tersebut terbebas dari heteroskedastisitas.

\section{Uji Multikolinearitas}

Menurut

(Gujarati, 2004). Multikolinieritas dilakukan untuk melihat apakah ada yerjadi hubungan antar variabel bebas atau tidak. Untuk melihat ada tidaknya mulitikolinieritas dapat dilihat dari koefisien korelasi dari masing-masing variabel bebas. Jika angka korelasi yang diperoleh lebih besar dari 8 maka terjadi multikolonearitas begitu juga sebaliknya.

\section{Pengujian Hipotesis}

\section{Uji t}

Uji t dilakukan untuk melihat apakah ada hubungan variabel bebas dan variabel terikat secara parsial (Subri, 2013). Adapun kriteria pengujiannya adalah sebagai berikut:

1. Jika $t_{\text {hitung }}>t_{\text {tabel }}$ Ho ditolak dan menerima Ha yang artinya variabel bebas (X) secara parsial mempengaruhi variabel terikat $(\mathrm{Y})$.

2. 2. Jika $t_{\text {hiutng }}<t_{\text {tabel }}$ maka Ho diterima dan menolak Ha yang artinya variabel bebas (X) secara parsial tidak mempengaruhi vaiabel terikat (Y).

\section{Uji F}

Uji F dilakukan untuk melihat apakah ada hubungan variabel bebas dan variabel terikat secara simultan (Subri, 2013). Adapun kriteria pengujiannya adalah sebagai berikut:

3. Jika $F_{\text {hitung }}>F_{\text {tabel }}$ Ho ditolak dan menerima Ha yang artinya variabel bebas (X) secara simultan mempengaruhi variabel terikat (Y).

4. 2. Jika $F_{\text {hiutng }}<F_{\text {tabel }}$ maka Ho diterima dan menolak Ha yang artinya variabel bebas (X) secara simultan tidak mempengaruhi vaiabel terikat (Y).

\section{Koefisien Korelasi (R)}

Menurut (Sugiyono, 2015) Koefisien korelasi untuk melihat sebesar besar angka hasilnya mempengaruhi variable lainnya sehingga dapat kita tetntukan hasilnya dalam standard mana. Hasilnya dapt ditentukan interpretasi koefisien sebagai berikut (Sugiyono, 2015):

- $>0,00-0,199=$ sangat rendah

- $>0,20-0,399=$ rendah

- $>0,40-0,599=$ sedang

- $>0,60-0,799=$ kuat

- $>0,80-0,99=$ sangat kuat

- $>1 \quad=$ korelasi sempurna

\section{Koefisien Determinasi $\left(R^{2}\right)$}

Koefisien determinasi $\left(R^{2}\right)$ adalah satu ukuran yang digunakan untuk mengukur pengaruh variabel independen terhadap variansi dependen, dengan $0<R^{2}<1$. Secara sederhana koefisien determinasi dihitung dengan mengkuadratkan Koefisien Korelasi (R). (Subri, 2013). 
Analisis Kontribusi Pendapatan Tenaga Kerja

\section{Wanita}

Untuk menghitung besarnya kontribusi pendapatan tenaga kerja wanita dari usaha belah Pinang di desa Paya Rangkuluh Kecamatan Kuta Blang Kabupaten Bireuen terhdap pendapatan total rumah tangga dihitung menurut rumus (Suroto, 2000) berikut:

Keterangan :

$$
K=\frac{P a}{P t R t} \times 100 \%
$$

$K=$ Kontribusi pendapatan tenaga kerja wanita usaha belah Pinang (\%)

$\mathrm{Pa}=$ Pendapatan tenaga kerja wanita dari usaha belah Pinang (Rp)

PtRt = Pendapatan total rumah tangga $(\mathrm{Rp})$

Total pendapatan total rumah tangga dihitung dengan menggunakan persamaan:

Keterangan:

$$
\text { PtRt }=P_{1}+P_{2}
$$

PtRt = Pendapatan total rumah tangga $(\mathrm{Rp})$

$P_{1} \quad=$ Pendapatan tenaga kerja wanita dari usaha belah Pinang (Rp)

$P_{2} \quad=$ Pendapatan anggota keluarga (Rp)

\section{HASIL PENELITIAN DAN PEMBAHASAN}

\section{Hasil Regresi Linier Berganda}

Untuk melihat hasil estimasi model penelitian data yang diolah dengan bantuan program Eviews versi 10 maka diperoleh hasil perhitungan analisis regresi seperti yang ditunjukkan pada gambar berikut ini:

\section{Tabel 2}

Hasil Analisis Regresi Linear Berganda

\begin{tabular}{|c|c|c|c|c|}
\hline Variable & Coefficient & Std. Error & t-Statistic & Prob. \\
\hline $\mathrm{C}$ & -3.100025 & 0.981669 & -3.157914 & 0.0023 \\
\hline $\operatorname{LOG}\left(\mathrm{X}_{1}\right)$ & 0.940391 & 0.061685 & 15.24513 & 0.0000 \\
\hline $\mathrm{X}_{2}$ & -0.005517 & 0.001081 & -5.103054 & 0.0000 \\
\hline $\mathrm{X}_{3}$ & -0.011015 & 0.003664 & -3.005979 & 0.0036 \\
\hline $\operatorname{LOG}\left(X_{4}\right)$ & 0.121060 & 0.065081 & 1.860156 & 006687 \\
\hline $\begin{array}{l}\text { R-squared } \\
\text { Adjusted R- }\end{array}$ & 0.798707 & F-statistic & \multicolumn{2}{|c|}{74.39761} \\
\hline squared & 0.787971 & $\begin{array}{l}\text { Prob(F-statistic) } \\
\text { Durbin-Watson } \\
\text { stat }\end{array}$ & \multicolumn{2}{|c|}{0.000000} \\
\hline
\end{tabular}
Dependent Variable: LOG(PRODUKTIVITAS_TKW)

Sumber: Hasil Penelitian, 2019 (data diolah)

Nilai konstanta sebesar -3.1000 artinya jika variabel upah, usia, tingkat pendidikan dan total pendapatan rumah tangga, maka variabel produktivitas tenaga kerja wanita juga akan konstan sebesar -3.1000 .

Nilai koefisien regresi Upah TKW sebesar 0,9403 menunjukkan hubungan positif yang memberi arti jika variabel Upah TKW meningkat sebesar $1 \%$ maka akan meningkatkan variable produktivitas tenaga kerja wanita sebesar 0,9403 $\mathrm{kg} /$ bulan, dengan asumsi usia, TP serta jumlah anggaran dalam rumah tangga dianggap konstan.

Nilai koefisien regresi usia tenaga kerja wanita sebesar -0.005 menunjukkan hubungan negatif yang memberi arti jika variabel usia tenaga kerja wanita meningkat sebesar 1 tahun maka akan menurunkan variabel produktivitas tenaga kerja wanita sebesar 0.005 tahun, dengan asumsi upah, tingkat pendidikan dan total pendapatan rumah tangga dianggap konstan, berarti dalam model ini tidak ada hubungan antara usia tenaga kerja wanita terhadap produktivitas tenaga kerja wanita.

Nilai koefisien regresi tingkat pendidikan tenaga kerja wanita sebesar -0,011 menunjukkan hubungan negatif yang memberi arti jika variabel tingkat pendidikan tenaga kerja wanita meningkat sebesar 1 tahun maka akan menurunkan variabel produktivitas tenaga kerja wanita sebesar $0.011 \%$, dengan asumsi upah, usia dan total pendapatan rumah tangga dianggap konstan, berarti dalam model ini tidak ada hubungan antara tingkat pendidikan tenaga kerja wanita terhadap produktivitas tenaga kerja wanita.

Nilai koefisien regresi total pendapatan rumah tangga wanita sebesar 0,121 menunjukkan hubungan positif yang memberi arti jika variabel total pendapatan rumah tangga wanita meningkat sebesar $1 \%$ maka akan meningkatkan variabel produktivitas tenaga kerja wanita sebesar $0,121 \%$, dengan asumsi upah, usia dan tingkat pendidikan dianggap konstan, berarti dalam model ini ada hubungan antara total pendapatan rumah tangga terhadap produktivitas tenaga kerja wanita.

\section{Uji Normalitas}

Hasil Uji normalitas dapat dilihat pada tabel gambar berikut ini:

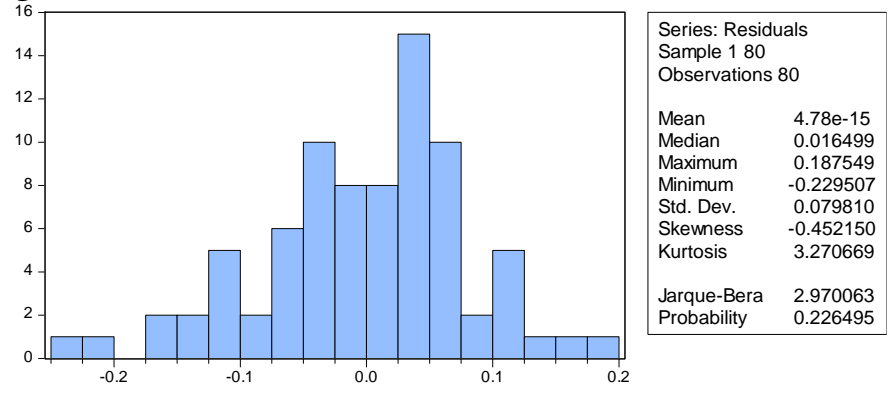

Sumber: Hasil Penelitian, 2019 (data diolah)

Gambar 2 Uji Normalitas 
Nilai $X^{2}$ tabel dengan df $(4)=9,48$. Jika dibandingkan dengan nilai J-B pada tabel diatas sebesar $2,97<9,48$, maka dapat disimpulkan bahwa model regresi, variabel penggangu atau residual dalam model sudah terdistribusi dengan normal. Hal ini juga bisa dilihat dari probabilitas (P-value) sebesar 0,22>0,05.

\section{Hasil Uji Asumsi Klasik}

\section{Hasil Uji Heteroskedastisitas}

Hasil uji heteroskedastisitas dapat dilihat pada tabel berikut ini:

\section{Tabel 3}

Uji Heteroskedastisitas

Heteroskedasticity Test: White

\begin{tabular}{lll}
\hline \hline F-statistic & 1.440937 & Prob. F(4,75) \\
Obs*R-squared & 5.709243 & Prob. Chi-Square(4) \\
Scaled explained SS & 5.696982 & Prob. Chi-Square(4)
\end{tabular}

Sumber: Hasil Penelitian, 2019 (data diolah)

Berdasarkan Tabel di atas menunjukkan bahwa bahwa data model yang digunakan dalam penelitian ini terbebas dari heteroskedastisitas, dari hasil tersebut dilihat dari obs*R-Squared < $X^{2}$ tabel pada df $(4)=9,48$ sehingga $5,71<9,48$. Hal ini juga bisa dilihat dari nilai probability ( $\mathrm{P}$ value) sebesar 0,22>0,05.

\section{Hasil Uji Multikolonearitas}

Hasil uji multikolinearitas dapat dilihat pada tabel berikut ini:

Tabel 4

Uji Multikolonearitas

\begin{tabular}{|c|c|c|c|c|}
\hline & Upah & Usia & $\begin{array}{c}\text { Tingkat } \\
\text { Pendidi } \\
\text { kan }\end{array}$ & $\begin{array}{c}\text { Total } \\
\text { Pendapat } \\
\text { an }\end{array}$ \\
\hline Upah & 1 & 0.033 & $-0,019$ & 0.263 \\
\hline Usia & 0.033 & 1 & $-0,872$ & 0.292 \\
\hline $\begin{array}{c}\text { Tingkat } \\
\text { Pendidikan }\end{array}$ & $-0,019$ & $-0,872$ & 1 & $-0,697$ \\
\hline $\begin{array}{c}\text { Total } \\
\text { Pendapatan }\end{array}$ & 0.263 & 0.292 & $-0,697$ & 1 \\
\hline
\end{tabular}

Sumber: Hasil Penelitian, 2019 (data diolah)

Berdasarkan Tabel di atas, diketahui bahwa nilai correlation matrix antar variabel bebas tidak melebihi 0,8, maka dapat dikatakan pada penelitian ini tidak terjadinya multikolinieritas pada empat variabel bebas ini.

\section{Pengujian Hipotesis}

Uji t ini:

Hasil pengujian dapat dilihat pada berikut

Tabel 5

Uji t

\begin{tabular}{|l|l|l|l|l|}
\hline \multicolumn{5}{|c|}{ Variabel Dependen (Pengeluaran pemerintah) } \\
\hline $\begin{array}{l}\text { Varibael } \\
\text { Independen }\end{array}$ & $\begin{array}{l}\text { T- } \\
\text { Statistik }\end{array}$ & Prob & Keterangan & Hipotesis \\
\hline Upah & 15.24513 & 0,0000 & Signifikan & Diterima \\
\hline Usia & - & 0,0000 & Signifikan & Diterima \\
\hline $\begin{array}{l}\text { Tingkat } \\
\text { Pendidikan }\end{array}$ & -3.103054 & & & \\
\hline Total & 1.860156 & 0,0687 & Signifikan & Diterima \\
\hline S9endapatan & & 0,0036 & Signifikan & Diterima \\
19 Sumber: Hasil Penelitian,2019 (data diolah)
\end{tabular}

Dari Tabel dapat dilihat bahwa nilai

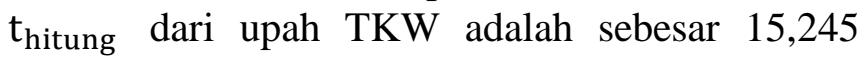
dengan nilai signifikannya adalah 0,0000, sementara nilai $t_{\text {tabel }}$ dengan $(\mathrm{df})=\mathrm{n}-\mathrm{k}(80-5)=$ 75 pada $\alpha=0,01$ diperoleh nilai sebesar 2,64 artinya kecil dari derajat kesalahan sebesar $1 \%$ $\left(0,01\right.$, maka keputusannya menolak $H_{0}$ dan menerima $H_{1}$, yang berarti secara parsial upah TKW berpengaruh positif terhadap produktivitas TKW pada usaha belah pinang di Desa Paya Rangkuluh Kecamatan Kuta Blang Kabupaten Bireuen.

Selanjutnya dilihat bahwa nilai $t_{\text {hitung }}$ dari usia tenaga kerja wanita adalah sebesar $-5,103$ dengan nilai signifikannya adalah 0,0000, sementara nilai $t_{\text {tabel }}$ dengan $(\mathrm{df})=\mathrm{n}-\mathrm{k}(80-5)=$ 75 pada $\alpha=0,01$ diperoleh nilai sebesar 2,64 artinya kecil dari derajat kesalahan sebesar $1 \%$ $(0,01)$. Maka keputusannya menolak $H_{0}$ dan menerima $H_{2}$, yang berarti secara parsial usia TKW berpengaruh negatif terhadap produktivitas TKW pada usaha belah pinang di Desa Paya Rangkuluh Kecamatan Kuta Blang Kabupaten Bireuen.

Dan dilihat bahwa nilai $t_{\text {hitung dari }}$ tingkat pendidikan TKW adalah sebesar -3,005 dengan nilai signifikannya adalah 0,0036 , sementara nilai $t_{\text {tabel }}$ dengan $(\mathrm{df})=\mathrm{n}-\mathrm{k}(80-5)=$ 75 pada $\alpha=0,01$ diperoleh nilai sebesar 2,64 artinya kecil dari derajat kesalahan sebesar $1 \%$ $(0,01)$. Maka keputusannya menolak $H_{0}$ dan menerima $H_{3}$, yang berarti secara parsial tingkat pendidikan tenaga kerja wanita berpengaruh negatif terhadap produktivitas TKW pada usaha 
belah pinang di Desa Paya Rangkuluh Kecamatan Kuta Blang Kabupaten Bireuen.

Kemudian dilihat bahwa nilai $t_{\text {hitung dari }}$ total pendapatan rumah tangga adalah sebesar 1.860 dengan nilai signifikannya adalah 0,0668 , sementara nilai $t_{\text {tabel }}$ dengan $(\mathrm{df})=\mathrm{n}-\mathrm{k}(80-5)=$ 75 pada $\alpha=0,1$ diperoleh nilai sebesar 1,66 artinya besar dari derajat kesalahan sebesar $10 \%$ $(0,1)$. Maka keputusannya menerima $H_{0}$ dan menolak $H_{4}$, yang berarti secara parsial total pendapatan rumah tangga berpengaruh positif terhadap produktivitas tenaga kerja wanita pada usaha belah pinang di Desa Paya Rangkuluh Kecamatan Kuta Blang Kabupaten Bireuen.

\section{Uji F}

\section{Tabel 6}

Uji F

\begin{tabular}{|l|l|l|l|l|}
\hline F-Statistik & T-tabel & Prob & Keterangan & Hipotesis \\
\hline 74.397 & 3,58 & 0,000000 & Signifikan & Diterima \\
\hline
\end{tabular}

Sumber: Hasil Penelitian, 2019 (data diolah)

Dari Tabel dapat diketahui bahwa nilai $F_{\text {hitung }}$ sebesar 74.397 dengan nilai signifikan sebesar 0,000 pada taraf kepercayaan $99 \%$. Sedangkan $F_{\text {tabel }}$ diperoleh nilai sebesar 3,58 pada $\alpha=0,01$. Dengan demikian $F_{\text {hitung }}>F_{\text {tabel }}$ yaitu $74.39>3,58$ dan nilai signifikan sebesar $0,000<0,01$. Dari hasil uji $\mathrm{F}$ ini berarti $H_{a}$ diterima atau menolak $H_{0}$, dengan demikian upah, usia, tingkat pendidikan dan total pendapatan rumah tangga secara bersama-sama berpengaruh positif terhadap produktivitas TKW pada usaha belah pinang di Desa Paya Rangkuluh Kecamatan Kuta Blang Kabupaten Bireuen.

\section{Koefisien Korelasi (R)}

Nilai koefisien korelasi adalah $R=\sqrt{R^{2}}=$ $\sqrt{0,7987}=0,8937(89,37 \%)$ yang menunjukkan bahwa hubungan antara variabel upah, usia, tingkat pendidikan dan total pendapatan rumah tangga terhadap produktivitas TKW, pada usaha belah pinang di Desa Paya Rangkuluh Kecamatan Kuta Blang Kabupaten Bireuen memiliki hubungan yang sangat kuat secara positif karena nilai korelasi 0,8937 mendekati positif satu $(+1)$.

\section{Koefisien Determinasi $\left(\boldsymbol{R}^{\mathbf{2}}\right)$}

Secara sederhana koefisien determinasi dihitung dengan mengkuadratkan koefisien korelasi (R).

Adjusted R-Squared $=0,7879$
Maka nilai koefisien determinasi $\left(R^{2}\right)$ sebesar 0,7879 yang artinya bahwa ada kaitan antara variabel bebas dan variabel terikat, perubahan yang terjadi pada variabel terikat dapat dijelaskan oleh variabel bebas sebesar 0,7879 $(78,79 \%)$, sedangkan yang dipengaruhi oleh variabel lain diluar model ini adalah sebesar 1$0,7879=0,2121(21,21 \%)$.

\section{Kontribusi Pendapatan}

Tabel 7

Kontribusi Pendapatan Tenaga Kerja Wanita Usaha Belah Pinang

\begin{tabular}{|c|l|c|}
\hline No & \multicolumn{1}{|c|}{ Uraian } & Rata-rata \\
\hline 1 & Pendapatan tenaga kerja wanita & Rp 432.938 \\
2 & (Rp/bulan) & Rp 2.645.000 \\
& $\begin{array}{l}\text { Pendapatan diluar tenaga kerja } \\
3\end{array}$ & wanita (suami) (Rp/bulan) \\
4 & Total Pendapatan Keluarga & 14.077 .938 \\
& (Rp/bulan) & $85,93 \%$ \\
& Kontribusi Pendapatan : & \\
& a. Tenaga kerja wanita & \\
\hline
\end{tabular}

Sumber: Hasil Penelitian, 2019 (data diolah)

Berdasarkan tabel diketahui bahwa rata-rata pendapatan tenaga kerja wanita pada usaha belah Pinang adalah Rp 432.938 meskipun masih terdapat beberapa tenaga kerja yang mendapatakan upah dibawah rata-rata upah per bulan tersebut. Namun bila dibandingkan dengan pendapatan suami maka maka upah tenaga kerja masih dianggap kurang. Kontribusi pendapatan yang mampu disumbangkan oleh tenaga kerja wanita terhadap pendapatan total keluarga adalah sebesar 14,07\%. Jumlah ini masih sangat kecil bila dibandingkan dengan kontribusi pendapatan suami yakni sebesar $85,93 \%$ yang disebabkan oleh rendahnya upah yang diterima tenaga kerja wanita namun waktu yang dicurahkan untuk bekerja lebih banyak.

\section{Pembahasan \\ Pengaruh Upah Terhadap Produktivitas}

Berdasarkan hasil analisis data ditemukan bahwa variabel upah tenaga kerja wanita $\left(X_{1}\right)$ berpengaruh secara positif terhadap produktivitas tenaga kerja wanita (Y) dengan nilai signifikan $\alpha=$ $1 \%$. Hal ini bermakna bahwa semakin tinggi upah $\left(X_{1}\right)$, maka semakin tinggi pula produktivitas tenaga kerja wanita pada usaha belah pinang di Desa Paya Rangkuluh Kecamatan Kuta Blang Kabupaten Bireuen.

Hasil penelitian ini sejalan dengan penelitian yang dilakukan oleh (Kurniati, 2010) di provinsi Riau bahwa upah tenaga kerja wanita berhubungan positif terhadap produktivitas tenaga kerja wanita, 
dimana setiap kenaikan Rp 1 upah tenaga kerja akan meningkatkan produktivitas tenaga kerja wanita. Kenaikan upah juga mendorong tenaga kerja untuk meningkatkan produktivitas dan bekerja lebih baik lagi.

\section{Pengaruh Usia Terhadap Produktivitas}

Berdasarkan hasil analisis data ditemukan bahwa variabel usia $\left(X_{2}\right)$ berpengaruh secara negatif terhadap produktivitas tenaga kerja wanita (Y) dengan nilai signifikan $\alpha=1 \%$. Hal ini bermakna bahwa tinggi usia $\left(X_{2}\right)$, maka semakin rendah produktivitas tenaga kerja wanita pada usaha belah pinang di Desa Paya Rangkuluh Kecamatan Kuta Blang Kabupaten Bireuen.

Hasil penelitian ini sejalan dengan penelitian yang dilakukan oleh (Kurniati, 2010) di Kabupaten Riau bahwa umur tenaga kerja wanita berpengaruh nyata pada produktivitas kerja wanita di agroindustri ikan patin.

\section{Pengaruh Tingkat Pendidikan Terhadap}

\section{Produktivitas}

Berdasarkan hasil analisis data ditemukan bahwa variabel tingkat pendidikan $\left(X_{3}\right)$ berpengaruh secara negatif terhadap produktivitas tenaga kerja wanita (Y) dengan nilai signifikan $\alpha=$ 1\%. Hal ini bermakna bahwa semakin besar tingkat pendidikan $\left(X_{3}\right)$, maka semakin rendah produktivitas tenaga kerja wanita pada usaha belah pinang di Desa Paya Rangkuluh Kecamatan Kuta Blang Kabupaten Bireuen.

Hasil penelitian ini sejalan dengan penelitian yang dilakukan oleh (Kurniati, 2010) di Provinsi Riau bahwa tingkat pendidikan tidak berpengaruh nyata terhadap produktivitas tenaga kerja wanita pada agroindustri ikan patin.

\section{Pengaruh Total Pendapatan Terhadap}

\section{Produktivitas}

Berdasarkan hasil analisis data ditemukan bahwa variabel total pendapatan rumah tangga $\left(X_{4}\right)$ berpengaruh secara positif terhadap produktivitas tenaga kerja wanita $(\mathrm{Y})$ dengan nilai signifikan $\alpha=10 \%$. Hal ini bermakna bahwa semakin besar total pendapatan $\left(X_{4}\right)$, maka semakin tinggi produktivitas tenaga kerja wanita pada usaha belah pinang di Desa Paya Rangkuluh Kecamatan Kuta Blang Kabupaten Bireuen.

Hasil penelitian ini sejalan dengan penelitian yang dilakukan oleh (Kurniati, 2010) di Provinsi Riau bahwa pendapatan rumah tangga berpengaruh nyata terhadap produktivitas tenaga kerja wanita pada agroindustri ikan patin.

\section{PENUTUP}

\section{Kesimpulan}

1. Hasil yang ditemukan variabel upah tenaga kerja wanita dan total pendapatan rumah tangga berpengaruh secara positif terhadap produktivitas tenaga kerja wanita. Adanya pengaruh ini menunjukkan bahwa seiring dengan terjadinya peningkatan upah, maka produktivitas tenaga kerja wanita juga akan meningkat.

2. Variabel usia tenaga kerja wanita dan tingkat pendidikan tenaga kerja wanita berpengaruh secara negatif terhadap produktivitas tenaga kerja wanita artinya semakin tinggi hasil variabel usia dan tingkat pendidikan, maka akan menurunkan produktivitas.

3. Secara bersama-sama variabel upah, usia, tingkat pendidikan dan total pendapatan rumah tangga berpengaruh positif terhadap produktivitas, dan besarnya pengaruh upah, usia, tingkat pendidikan dan total pendapatan rumah tangga berpengaruh positif terhadap produktivitas adalah sebesar $78,79 \%$ dan sisanya sebesar $(1-78,79 \%)=21,21 \%$ dapat dijelaskan diluar model penelitian ini.

4. Kontribusi pendapatan yang mampu disumbangkan oleh tenaga kerja wanita terhadap pendapatan total keluarga adalah sebesar $14,07 \%$. Jumlah ini masih sangat kecil bila dibandingkan dengan kontribusi pendapatan suami yakni sebesar $85,93 \%$ yang disebabkan oleh rendahnya upah yang diterima tenaga kerja wanita namun waktu yang dicurahkan untuk bekerja lebih banyak.

\section{Saran}

Adapun beberapa saran-saran yang diharapkan penulis dalam penelitian ini adalah sebagai berikut:

1. Diharapkan kepada pemilik usaha agar dapat menstandarkan upah bagi pekerjanya agar hidup mereka lebih sejahtera.

2. Mengintensikan kembali bahwa usaha belah pinang merupakan usaha yang sangat produktif dimasyarakat, karena usaha ini merupakan usaha yang menciptakan lapangan kerja bagi kebutuhan masyarakat untuk memenuhi kebutuhan sehari-hari.

3. Diharapkan kepada Pemerintah setempat agar mensosialisasikan pentinganya pembelajaran 
dalam proses pertania, agar tercipta pohonpohon pinang yang baik dan berkualitas.

\section{DAFTAR PUSTAKA}

Akbar, Y. R. (2017). Analisis Faktor - Faktor Yang Mempengaruhi Produktivitas Industri Furniture Kaca Dan Alumunium Di Kota Pekanbaru. Jom FEKON, Vol. 4(No.1).

Ardi, N. L. (2011). Pengantar Kebutuhan Dasar Manusia. Jakarta: Salemba Mitra Wacana.

Arsyad, L. (2010). Ekonomi Pembangunan. Jakarta: Salemba Empat.

Bonanta, H. (2015). Faktor-Faktor Yang Mempengaruhi Produktivitas Industri Makanan Di Propinsi Riau. Journal Of Economyc, Vol 3(No 1).

D, A. P. dan S. (2002). Koperasi, Kewirausahaan dan Usaha Kecil. Jakarta: Rineka Cipta.

Djumransyah. (2004). Pengantar Filsafat Pendidikan (Bayumedia). Malang.

Fair, C. \&. (2007). Prinsip-Prinsip Ekonomi Mikro. (Y. Andri Zaimur. Terjemahan). Jakarta: Erlangga.

Farida, L. (2011). Kontribusi Pendapatan Perempuan Bekerja Sektor Informal Pada Ekonomi Keluarga di Kota Pekanbaru. Aplikasi Bisnis, 1(2).

Ghozali, I. (2010). Aplikasi Analisis Multivariate dengan Program SPSS Edisi I. Bogor: Universitas Dipenogoro.

Gilarso. (2013). Pengantar ilmu Ekonomi Mikro. Yogyakarta: Kanisius.

Gujarati, D. (2004). Ekonometrika Dasar Terjemahan: Sumarno Zain. Jakarta: PT. Erlangga.

Jaya. (2011). Faktor-faktor yang Mempengaruhi Pendapatan Pedagang Kaki Lima di Sekitar Pantai Losari Kota Makkasar. Makassar.

Kurniati, Y. (2010). Dinamika Indutri Manufaktur dan Respon Terhadap Siklus Bisnis. Jurnal UNDIP, 3(2).

Nur, H. M. (2013). Pengaruh Modal Dan Tenaga Kerja Usaha Pengrajin Batik Tulis Klasik Terhadap Tingkat Produktivitas (Studi Pada Industri Kecil Menengah “ Ikm “ Batik Tulis Klasik Di Desa Margorejo, Kecamatan Kerek, Kabupaten Tuban). Jurnal Jejak, Vo 3(No 2).

Purwanti. (2014a). Pengaruh Jumlah Tanggungan Keluarga, Pendapatan Terhadap produktivitas Tenaga Kerja Wanita Pada Industri Kerupuk Kedelai di Tuntang Kabupaten Semarang. Jurnal Among Makarti, Vol 7 No.
Rahman, A. (2012). Doktrin Ekonomi Jilid 2. Jakarta: Salemba Empat.

Samuelson, P. A. dan W. D. N. (2001). Ilmu Mikro Ekonomi. Jakarta: PT Media Global Edukasi.

Sermy, M. (2015). Analisis Faktor-Faktor Yang Mempengaruhi Produktivitas Industri Furnitur Dari Alumunium Di Kota Pekanbaru. Jom FEKON, Vol 2(No. 2).

Simanjuntak, P. (2001). Pengantar Ekonomi Sumber Daya Manusia. Jakarta: Lembaga Penerbit Fe-Ui.

Suarbawa, I Wayan, Terimajaya I Wayan, D. A. P. F. (2016). Pengaruh Umur, Jumlah Tanggungan Dan Jam Kerja Terhadap produktivitas Tenaga Kerja Pengrajin Di Kecamatan Kediri. Ilmiah Untab, 13(2).

Subri. (2013). Ekonomi Sumber Daya Manusia. (P. R. G. Persada, Ed.). Jakarta.

Sugiyono. (2015). Statistik Untuk Penelitian. Bandung: Alfabeta.

Sukirno, S. (2004). Pengantar Teori Makro. Jakarta: PT. Graha Grafindo.

Sukirno, S. (2015). Makro Ekonomi Teori pengantar Edisi Ketiga. Jakarta: PT. Rajawali Pers.

Suroto. (2000). Apresiasi Sastra Indonesia. Jakarta: PT. Erlangga.

Swastha, B. dan I. S. (2000). Pengantar Bisnis Modern. Yogyakarta: Liberty.

Undang-Undang No. 20 Tahun 2003. (n.d.). Sistem Pendidikan Nasional.

Wahyono, B. (2017). Analisis Faktor-faktor yang Mempengaruhi Pendapatan Pedagang di Pasar Bantul Kabupaten Bantul. Pendidikan Dan Ekonomi, 6(4).

Widarjono, A. (2013). Ekonometrika. Yogyakarta: Edisi Keempat. 